\title{
亚硫酸钠介导的 $s^{4} U$ 转化检测转录组新生 RNA 中 $m^{6} A$
}

\author{
危琦 韩少卿门陈玉琪门周翔* \\ (武汉大学 化学与分子科学学院 武汉 430072)
}

\begin{abstract}
摘要 发展了亚硫酸钠介导的 4-硫代尿苷 $\left(\mathrm{s}^{4} \mathrm{U}\right)$ 转化为胞苷 $(\mathrm{C})$ 的方法, 用 $\mathrm{s}^{4} \mathrm{U}$ 标记新生 $\mathrm{RNA}$, 通过反应将 $\mathrm{s}^{4} \mathrm{U}$ 转化为 $\mathrm{C}$ 可成功检测新生 RNA. 将新生 RNA 使用 $\mathrm{s}^{4} \mathrm{U}$ 标记后进行反应, 再使用 $\mathrm{m}^{6} \mathrm{~A}$ 抗体对 $\mathrm{m}^{6} \mathrm{~A}$ 片段进行富集, 从 $\mathrm{m}^{6} \mathrm{~A}$ 中分析 $\mathrm{T}$ 到 $\mathrm{C}$ 突变位点便成功区分出含 $\mathrm{m}^{6} \mathrm{~A}$ 的新生 RNA. 该方法有希望应用于单个基因上 $\mathrm{m}^{6} \mathrm{~A}$ 的动态变化检测, 有助于人 们进一步了解 $\mathrm{m}^{6} \mathrm{~A}$ 的修饰机制, 为 $\mathrm{m}^{6} \mathrm{~A}$ 功能研究提供新的方法.
\end{abstract}

关键词＼cjkstart亚硫酸钠; 新生 RNA; 4-硫代尿苷; N6-甲基腺嘌呤

\section{Sodium Sulfite-Mediated $s^{4} U$ Conversion for $m^{6} A$ Profiling of Nascent Transcriptome-Wide RNA

\author{
Qi Wei $^{\dagger} \quad$ Shaoqing $\mathrm{Han}^{\dagger} \quad$ Yuqi Chen ${ }^{\dagger} \quad$ Xiang Zhou* \\ (College of Chemistry and Molecular Sciences, Wuhan University, Wuhan 430072, China)
}

\begin{abstract}
RNA sequencing can profile gene expression at steady-state level but is weak in studying temporal RNA dynamics. A common method for nascent RNA analysis is metabolic labeling with nucleoside analog. We developed a method for nascent RNA sequencing based on sodium sulfite-mediated 4-thiouridine-to-cytidine ( $\mathrm{s}^{4} \mathrm{U}$-to-C) conversion. The RNA contained $\mathrm{s}^{4} \mathrm{U}$ is reacted in the buffer $\left(10 \mathrm{mmol} / \mathrm{L} \mathrm{Na}_{2} \mathrm{SO}_{3}, 200 \mathrm{mmol} / \mathrm{L} \mathrm{NH}_{4} \mathrm{Cl}\right.$ and $\left.200 \mathrm{mmol} / \mathrm{L} \mathrm{Na}_{2} \mathrm{HPO}_{4} / \mathrm{NaH}_{2} \mathrm{PO}_{4}, \mathrm{pH} 7.4\right)$ at $70{ }^{\circ} \mathrm{C}$ for $4 \mathrm{~h}$, the yield can reach more than $90 \%$. This method can efficiently distinguish nascent RNA information from total RNAs. SUC-seq is used to investigate the $\mathrm{m}^{6} \mathrm{~A}$, which is the most prevalent modification in mammalian mRNA and has been shown to have an essential regulatory role in the control of gene expression. Here, we provide a time resolved high-resolution profiling of $\mathrm{m}^{6} \mathrm{~A}$ on nascent RNA transcripts. $3 \times 10^{6} \mathrm{HEK} 293 \mathrm{~T}$ cells were seeded per 10 -cm cell dish and grown for $24 \mathrm{~h}$. Then, $\mathrm{s}^{4} \mathrm{U}$ was added to the medium at a final concertation of $500 \mu \mathrm{mol} / \mathrm{L}$ chased for $0,10,15,30,60,120$ and $240 \mathrm{~min}$. Total RNA was extracted using TRIzol reagent. $10 \mu \mathrm{g}$ total RNA was fragmented using RNA fragmentation reagents at $70{ }^{\circ} \mathrm{C}$ for $10 \mathrm{~min}$ after gDNA was removed. Fragmented RNA was then subjected to $\mathrm{s}^{4} \mathrm{U}$ reaction to realize the conversion of $\mathrm{s}^{4} \mathrm{U}$ to $\mathrm{C}$. Subsequently, $5 \mu \mathrm{g}$ treated RNA were taken to perform $\mathrm{m}^{6} \mathrm{~A}$ immunoprecipitation. After removing rRNA, library was constructed and perform next-generation sequencing. A large number of $\mathrm{T}$ to $\mathrm{C}$ mutations were observed in the mapping reads. The $\mathrm{T}$ to $\mathrm{C}$ mutation rate of the control RNA was kept at a low background level. The results show that our method can successfully distinguish nascent RNA from total RNA. Via analyzing the nascent RNA in $\mathrm{m}^{6} \mathrm{~A}$, the nascent $\mathrm{m}^{6} \mathrm{~A}$ can be distinguished from the total $\mathrm{m}^{6} \mathrm{~A}$. This method can be a promising strategy to study the mechanism and function of $\mathrm{m}^{6} \mathrm{~A}$.
\end{abstract}

Keywords sodium sulfite; nascent RNA; 4-thiouridine; N6-methyladenosine

\section{1 引言}

在 RNA 中除了四种天然存在的碱基之外, 还存在 着大量的修饰碱基，它们对生命体正常的生长发育过程 有着重要的影响. 在真核生物 mRNA 和长链非编码 RNA 中, $m^{6} \mathrm{~A}$ 是一种含量最丰富的转录后修饰 ${ }^{[1]}$. 其在 调控 RNA 转录、加工、剪接、翻译及 RNA 稳定性方面 都起着重要作用 ${ }^{[2]}$. mRNA 中的动态修饰对于基因表达 的转录后调控起着至关重要的作用 ${ }^{[3-4]}$. 从发现 FTO (fat mass and obesity-associated)蛋白可以与 $\mathrm{m}^{6} \mathrm{~A}$ 相互作用, 产生去甲基化作用之后 ${ }^{[5]}$, 对 $\mathrm{m}^{6} \mathrm{~A}$ 相关蛋白的研究以及 $\mathrm{m}^{6} \mathrm{~A}$ 检测技术的发展取得了很多重大的突破, 对 $\mathrm{m}^{6} \mathrm{~A}$ 相 关功能研究获得了长足的发展.

传统的 $\mathrm{m}^{6} \mathrm{~A}-\mathrm{seq}$ 技术通常是在细胞 RNA 的稳态水 平上进行的, 无法轻易区分 $\mathrm{m}^{6} \mathrm{~A}$ 在 RNA 上修饰的变化. 另外, 它不能很好地分辨 $\mathrm{m}^{6} \mathrm{~A}$ 修饰的动态变化信息. 了 解 $\mathrm{m}^{6} \mathrm{~A}$ 在生长发育过程中何时进行修饰有利于理解 $\mathrm{m}^{6} \mathrm{~A}$ 修饰所发挥的生物学功能. 研究新生 RNA 上的 $m^{6} \mathrm{~A}$ 修饰的变化对理解 $\mathrm{m}^{6} \mathrm{~A}$ 的功能具有重要意义.

新生 RNA 分析可以揭示基因表达变化的时间信息. 新生 RNA 通过代谢标记然后经过下游纯化处理, 再进 行 RNA 测序, 已成为研究新生 RNA 行为的经典手段.

\footnotetext{
* E-mail: xzhou@whu.edu.cn

$\uparrow$ These authors contributed equally to this work.

Received October 15, 2020; published November 27, 2020.

Project supported by the National Natural Science Foundation of China (Nos. 91753201, 21721005, 21907079).

项目受国家自然科学基金(Nos. 91753201, 21721005, 21907079)资助.
} 
对新生 RNA 研究以 4-硫脲 $\left(\mathrm{s}^{4} \mathrm{U}\right)$ 对 RNA 的代谢标记应 用最广泛 ${ }^{[6]}, s^{4} U$ 可以在转录时被掺杂进入 RNA, 通过对 $\mathrm{s}^{4} \mathrm{U}$ 标记的检测, 能够以单碱基分辨率将新生 RNA 与总 RNA 直接区分开从而达到检测新生 RNA 的目的.

近年来, 基于检测 $\mathrm{s}^{4} \mathrm{U}$ 研究新生 RNA 开发了许多的 方法. SLAM seq 使用碘代乙酰胺(IAA)对 $s^{4} U$ 进行亲核 取代反应使 $s^{4} U$ 烷基化, 在逆转录的过程中会产生 $s^{4} U$ 到 $\mathrm{C}$ 的突变 ${ }^{[7]}$. TimeLapse-seq 将 $\mathrm{s}^{4} \mathrm{U}$ 转化为胞嘧啶衍生 物, 该策略使用过氧化物将 $\mathrm{s}^{4} \mathrm{U}$ 中的硫 $(\mathrm{S})$ 为磺酸基 $\left(\mathrm{SO}^{3^{-}}\right)$再使用氨基衍生物进行取代反应 ${ }^{[8]}$. TUC-seq 同 样也是采用氧化的策略, 通过四氧化锇 $\left(\mathrm{OsO}_{4}\right)$ 将 $\mathrm{s}^{4} \mathrm{U}$ 氧 化后使用氨水取代反应将 $s^{4} U$ 直接转化为 $C^{[9]}$. AMUC-seq 使用丙烯腈对 $s^{4} U$ 的加成反应实现了 $s^{4} U$ 到 $\mathrm{C}$ 的突变 ${ }^{[10]}$. 在本文中, 我们采用了一种基于亚硫酸钠 的新方法实现 $\mathrm{s}^{4} \mathrm{U}$ 到 $\mathrm{C}$ 的转化, 该方法选择性高, 对其 他碱基影响很小. 可以成功用于转录组新生 RNA 的检 测. 使用 $s^{4} U$ 以时间脉冲的方式对新生 RNA 进行标记. 然后利用 $\mathrm{m}^{6} \mathrm{~A}-\mathrm{seq}$ 对 HEK293T 细胞中 $\mathrm{m}^{6} \mathrm{~A}$ 进行富集, 能够成功地分析出含有 $\mathrm{m}^{6} \mathrm{~A}$ 的新生 RNA.

\section{2 结果与讨论}

\section{1 亚硫酸钠介导的 $s^{4} U$ 到 $C$ 的转化}

$s^{4} U$ 可被氧化生成 $\mathrm{SO}^{3-}$ 产物, 而后很容易发生取代 反应. 我们使用亚硫酸钠与 $s^{4} U$ 发生加成反应生成 $\mathrm{SO}^{3^{-}}$取代产物, 然后与氯化铵 $\left(\mathrm{NH}_{4} \mathrm{Cl}\right)$ 反应可将 $\mathrm{s}^{4} \mathrm{U}$ 转 化为 $\mathrm{C}$ (图 1a). 通过优化实验条件发现, 在 $\mathrm{pH}$ 为 7.4 的 $10 \mathrm{mmol} / \mathrm{L}$ 亚硫酸钠 $\left(\mathrm{Na}_{2} \mathrm{SO}_{3}\right)$ 以及 $200 \mathrm{mmol} / \mathrm{L}$ 氯化铵 $\left(\mathrm{NH}_{4} \mathrm{Cl}\right)$ 反应液中 $\mathrm{s}^{4} \mathrm{U}$ 于 $37{ }^{\circ} \mathrm{C}$ 下 $1 \mathrm{~h}$ 内可快速转化为 $\mathrm{C}$.
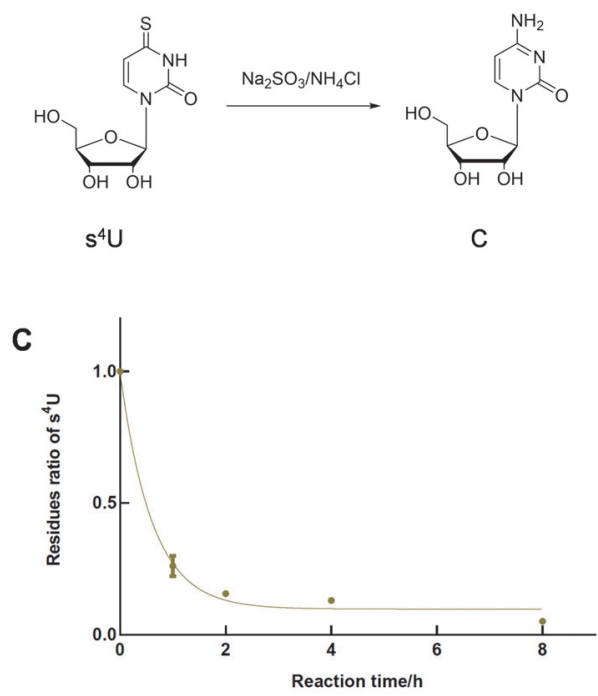

我们使用 $1 \mathrm{mmol} / \mathrm{L} A 、 \mathrm{U} 、 \mathrm{C} 、 \mathrm{G} 、 \mathrm{~s}^{4} \mathrm{U}$ 五种核苷在反应 液中反应，反应经过 HPLC 监测，A、U、C、G 四种碱 基无反应而 $s^{4} U$ 可完全反应，通过质谱与核磁鉴定生成 产物为 $\mathrm{C}$ (图 1b). 但使用此条件用于 RNA 反应时发现在 此条件下 RNA 链降解严重. 我们尝试使用了不同的缓 冲溶液体系进行反应，当使用 $200 \mathrm{mmol} / \mathrm{L}$ 磷酸钠缓冲 溶液时可防止 RNA 降解.

使用含 $\mathrm{s}^{4} \mathrm{U}$ 的转录本探究转化反应效率, 为了减少 对复杂的 RNA二级结构造成的 $\mathrm{s}^{4} \mathrm{U}$ 转化反应的影响, 在 反应之前, 将 mRNA 打断为约 $150 \mathrm{nt}$ 的 RNA 片段. 反 应后对 RNA 酶解, 通过 LC-MS 分析 mRNA 中 $\mathrm{s}^{4} \mathrm{U}$ 转 化的反应效率. LC-MS 分析鉴定出 $70{ }^{\circ} \mathrm{C}$ 反应 $4 \mathrm{~h}$ 总 mRNA 中近 $90 \%$ 的 $\mathrm{s}^{4} \mathrm{U}$ 转化为 $\mathrm{C}$ (图 1c).

为进一步验证反应效率和反应生成物, 使用含 $\mathrm{s}^{4} \mathrm{U}$ 的模式链反应并进行一代测序分析, $s^{4} U$ 位点成功转变 成 $\mathrm{C}($ 图 1d), 进一步说明了反应效率以及用于检测新生 RNA 的可行性.

\section{2 二代测序分析新生 RNA}

把细胞在含 $500 \mu \mathrm{mol} / \mathrm{L} \mathrm{s}^{4} \mathrm{U}$ 的培养基孵育不同时间 (10 min, $15 \mathrm{~min}, 30 \mathrm{~min}, 1 \mathrm{~h}, 2 \mathrm{~h}, 4 \mathrm{~h}$ ) 提取得到的总 RNA 经过转化反应后进行 $\mathrm{m}^{6} \mathrm{~A}$ 免疫共沉淀, 去除 $\mathrm{rRNA}$ 后进 行文库构建和高通量测序.

我们选取孵育时间为 $2 \mathrm{~h}$ 的样品与对照组相比进行 分析, 经转化反应处理的 RNA 中观察到大量的 $\mathrm{T}$ 到 $\mathrm{C}$ 突变, 其他类型突变不受影响, $\mathrm{T}$ 到 $\mathrm{C}$ 突变的频率经计 算为 $2.74 \%$. 对照 RNA 的 $\mathrm{T}$ 到 $\mathrm{C}$ 突变率保持在较低的 背景水平(图 2). 结果表明我们的方法能成功地从总 RNA 中区分出新生 RNA.
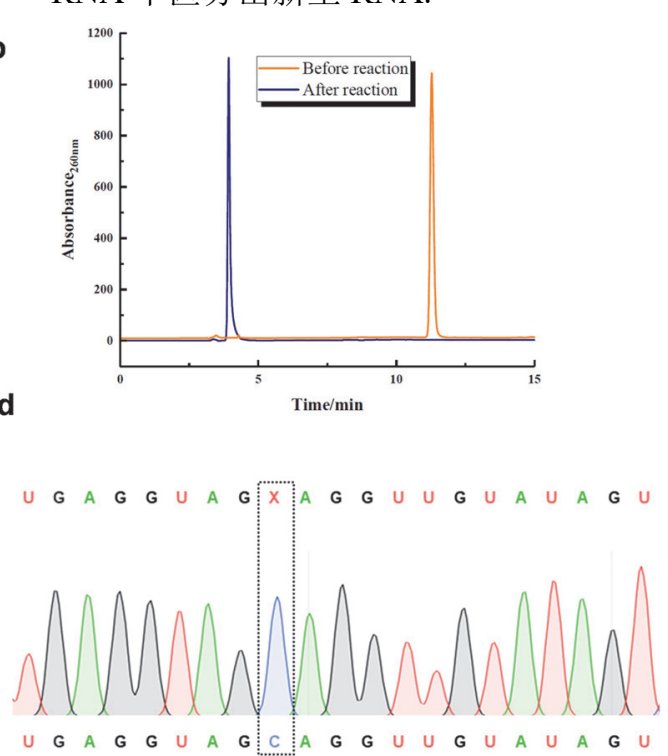

图 $1 s^{4} U$ 转化为 C. (a) $s^{4} U$ 在亚硫酸钠介导下与氯化氨反应生成 C. (b) HPLC 检测 $1 \mathrm{mmol} / \mathrm{L} \mathrm{s} \mathrm{s}^{4} \mathrm{U}$ 在 $37{ }^{\circ} \mathrm{C}$ 反应体系中反应 $1 \mathrm{~h}$ 生成 C. (c) LC-MS 检测含 $s^{4} U$ 转录本转化反应反应效率. (d) $T A$ 克隆测序验证 $s^{4} U$ 位点成功突变为 $C, X=s^{4} U$.

Figure $1 s^{4} U$ conversion to $C$. (a) The reaction of $s^{4} U$ with $\mathrm{NH}_{4} \mathrm{Cl}$ form $\mathrm{C}$ mediated by sodium sulfite. (b) Detect $\mathrm{s}^{4} \mathrm{U}$ reaction efficiency by HPLC. 1 $\mathrm{mmol} / \mathrm{L} \mathrm{s}{ }^{4} \mathrm{U}$ was incubated in the buffer at $37{ }^{\circ} \mathrm{C}$ for $1 \mathrm{~h}$. (c) Detection of $\mathrm{s}^{4} \mathrm{U}$ conversion reaction efficiency of by LC-MS. (Residues ratio of $\mathrm{s}^{4} \mathrm{U}$ is the $s^{4} \mathrm{U}$ content after the reaction/the initial s${ }^{4} \mathrm{U}$ ). (d) TA-cloning study to test the feasibility of the strategy for RNA. The $\mathrm{s}^{4} \mathrm{U}$ is mutated to $\mathrm{C}$ after reaction, $\mathrm{X}$ $=\mathrm{s}^{4} \mathrm{U}$. 


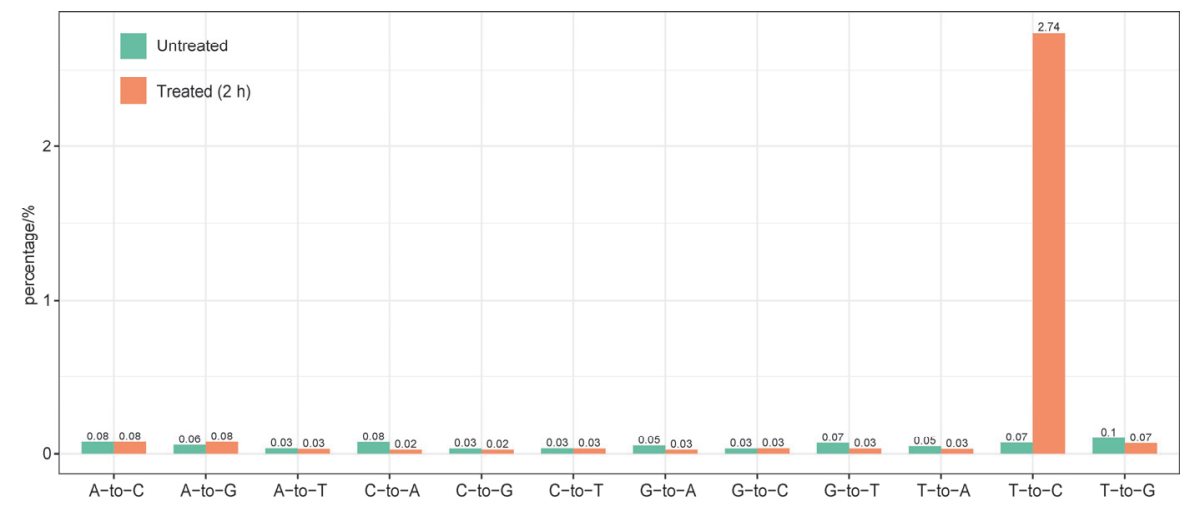

图 $2 \mathrm{~s}^{4} \mathrm{U}$ 标记 $2 \mathrm{~h}$ 的 RNA 反应后在转录组进行测序检测. 测序文库中所有可能突变类型的比率.

Figure 2 RNA labeled with $\mathrm{s}^{4} \mathrm{U}$ for $2 \mathrm{~h}$ after the reaction and then sequencing at transcriptome-wide scale. Mutation rates of all possible mutation types in the sequencing libraries.

\section{$2.3 \mathrm{~m}^{6} \mathrm{~A}$ 免疫共沉淀分析}

在 $s^{4} U$ 孵育不同时间点的样品进行 $m^{6} \mathrm{~A}$ 免疫共沉 淀, 对不同时间点样品表达量分析, 各样品之间的表达 量无明显差异, 表明加入 $\mathrm{s}^{4} \mathrm{U}$ 对 $\mathrm{m}^{6} \mathrm{~A}$ 表达没有影响(图 $3 a$ ), 我们分析了总 RNA 中新生 RNA 和 $m^{6} \mathrm{~A}$ 新生 RNA 的半衰期. 在转录本上, 总新生 RNA 的半衰期和 $\mathrm{m}^{6} \mathrm{~A}$ 新生 RNA 半衰期没有显著差异(图 $3 b$ ), 说明新生 $\mathrm{m}^{6} \mathrm{~A}$ 位点的基因与新生总 RNA 基因在组成上没有差异, 具 有一致性. 这些结果表明 $\mathrm{s}^{4} \mathrm{U}$ 的加入对转录组 RNA 的表 达以及 $\mathrm{m}^{6} \mathrm{~A}$ 的修饰无明显影响.

对 $\mathrm{m}^{6} \mathrm{~A}$ 富集后根据 $\mathrm{T}$ 到 $\mathrm{C}$ 的突变从 $\mathrm{m}^{6} \mathrm{~A}$ 片段中挑 出 $s^{4} U$ 标记的 $m^{6} \mathrm{~A}$ 并对其进行分析, 随着 $s^{4} U$ 餒育时间 增加, $\mathrm{m}^{6} \mathrm{~A}$ 中片段中突变比例随之变高(图 4a). 热图显 示了不同时间点被 $\mathrm{s}^{4} \mathrm{U}$ 标记的 $\mathrm{m}^{6} \mathrm{~A}$ 位点基因组成上的变 化差异. 从中我们可以得知 $\mathrm{m}^{6} \mathrm{~A}$ 在基因表达过程中的 修饰具有偏向性.

高通量测序分析 RNA 转录组区总 $\mathrm{m}^{6} \mathrm{~A}$ 位点的分布, 我们鉴定出有 1716 个 peaks 在 $3^{\prime}$ 非编码区, 1874 个 peaks 在 CDS 区, 463 个 peaks 在 5'非编码区(图 5a) 以及 $\mathrm{m}^{6} \mathrm{~A}$ 在基因区段上的比例(图 5c). 我们选取 $\mathrm{s}^{4} \mathrm{U}$ 标记时间为

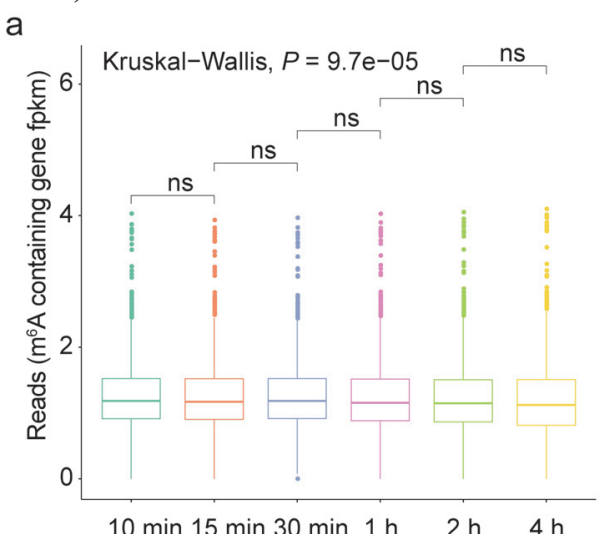

$30 \mathrm{~min}$ 突变比例大于 $20 \%$ 的位点判定为新生 $\mathrm{m}^{6} \mathrm{~A}$ 位点 进行分析, 我们发现这些位点均在 mRNA 上, 在 CDS 区有 166 个, 在 $3^{\prime}$ 非编码区有 211 个, 在 $5^{\prime}$ 非编码区有 36 个(图 5b)以及新生 $\mathrm{m}^{6} \mathrm{~A}$ 在基因区段上的比例(图 5d). 从总 $\mathrm{m}^{6} \mathrm{~A}$ 与新生 $\mathrm{m}^{6} \mathrm{~A}$ 分布比较我们可以观察到新生 $\mathrm{m}^{6} \mathrm{~A}$ 上 $3^{\prime}$ 非编码区所占比例有所上升. 新生 $\mathrm{m}^{6} \mathrm{~A}$ 和总 $\mathrm{m}^{6} \mathrm{~A}$ 在 motif 上没有差异(图 5e)且与经典的 motif 序列一 致.

$\mathrm{m}^{6} \mathrm{~A}$ 位点主要分布于终止密码子附近(图 $\left.5 \mathrm{f}\right)$. 我们 能够发现新生 $\mathrm{m}^{6} \mathrm{~A}$ 位点与总体 $\mathrm{m}^{6} \mathrm{~A}$ 位点的差异性, 这 些差异可能与早期 $\mathrm{m}^{6} \mathrm{~A}$ 对基因的转录调控有关.

接着我们选择 KIF1B 基因分析在新生 RNA 中 $\mathrm{m}^{6} \mathrm{~A}$ 位点 1 (peak1)和 $\mathrm{m}^{6} \mathrm{~A}$ 位点 2 (peak2)修饰水平的变化(图 $6 \mathrm{a}, 6 \mathrm{~b})$, 并与总体 $\mathrm{m}^{6} \mathrm{~A}$ 修饰水平变化比较(图 6c), 发现 在总新生 RNA 上 $\mathrm{m}^{6} \mathrm{~A}$ 修饰水平随着 $\mathrm{s}^{4} \mathrm{U}$ 标记时间增长 而稳定增加，而 KIF1B 上的修饰变化趋势不同于总体 $\mathrm{m}^{6} \mathrm{~A}$ 修饰变化趋势. 这暗示单个基因上的 $\mathrm{m}^{6} \mathrm{~A}$ 修饰变化 不同于整体修饰变化, 并可以通过该方法捕捉到单个基 因上 $\mathrm{m}^{6} \mathrm{~A}$ 的修饰变化信息.

b

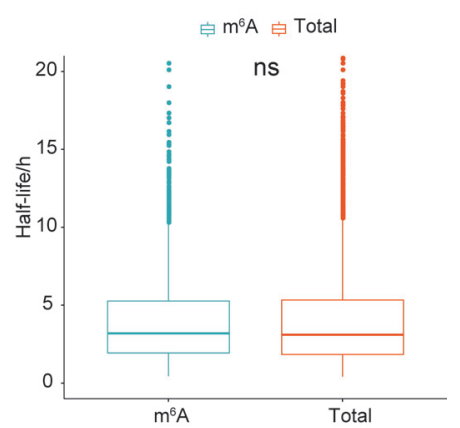

图 3 RNA 表达量差异性评估. (a) 箱线图显示对 $s^{4} U$ 捊育不同时间的 $\mathrm{m}^{6} \mathrm{~A}$ 各组之间无显著差异. (b) 箱线图显示 $\mathrm{m}^{6} \mathrm{~A}$ 峰上的基因与总体基因半 衰期无显著差异.

Figure 3 Evaluation of the difference in expression level of markers at different times. (a) Box plot shows that there is no significant difference between the groups of $\mathrm{m}^{6} \mathrm{~A}$ incubated at different times for $\mathrm{s}^{4} \mathrm{U}$. (b) Box plot shows that the gene on the $\mathrm{m}^{6} \mathrm{~A}$ peak is not significantly different from the overall gene. 


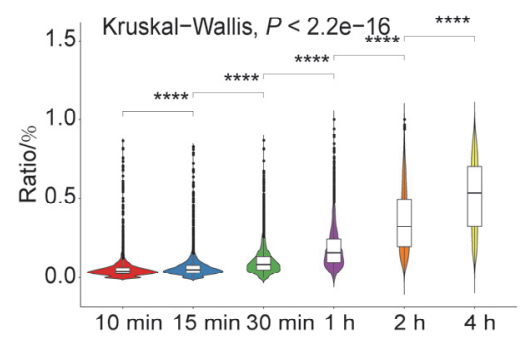

b

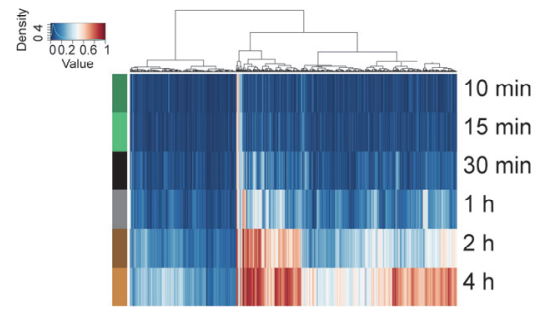

图 4 新生 $m^{6} \mathrm{~A}$ 表达量. (a) 小提琴图显示随着标记时间增加, $m^{6} \mathrm{~A}$ peak 中 $\mathrm{s}^{4} \mathrm{U}$ 含量增加. (b) 热图显示被 $\mathrm{s}^{4} \mathrm{U}$ 标记的 $\mathrm{m}^{6} \mathrm{~A}$ 种类变化趋势.

Figure 4 Nascent $\mathrm{m}^{6} \mathrm{~A}$ expression. (a) Violin chart shows that the $\mathrm{s}^{4} \mathrm{U}$ content in the $\mathrm{m}^{6} \mathrm{~A}$ peak increases as the marking time increases. (b) Heat map shows the change trend of $\mathrm{m}^{6} \mathrm{~A}$ species marked by $\mathrm{s}^{4} \mathrm{U}$.

a

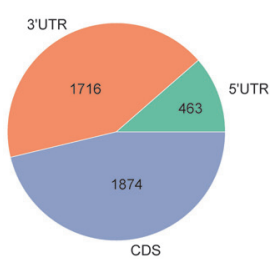

b

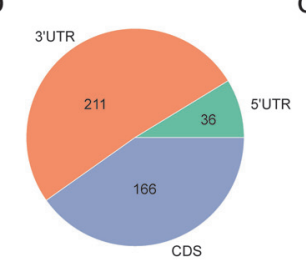

C

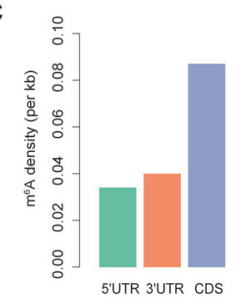

d

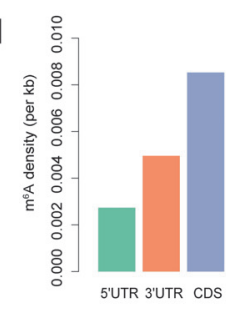

e

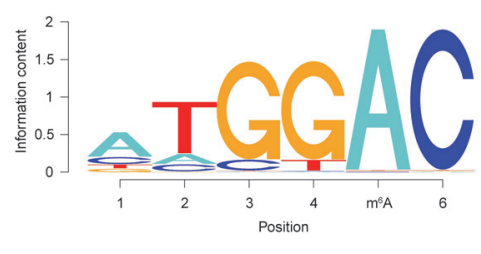

f

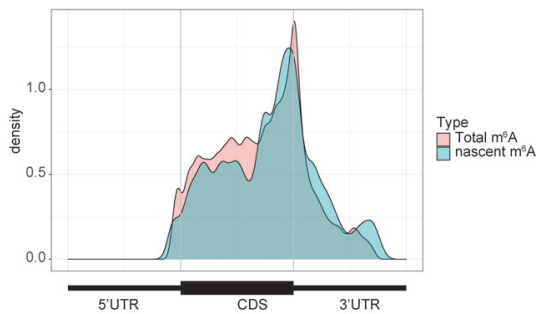

图 5 高通量测序分析新生 $\mathrm{m}^{6} \mathrm{~A}$ 和总 $\mathrm{m}^{6} \mathrm{~A}$. (a) 饼图显示了非重叠 $\mathrm{RNA}$ 片段中 $\mathrm{m}^{6} \mathrm{~A}$ 位点的比例. (b) 饼图显示了非重叠新生 RNA 片段中 $\mathrm{m}^{6} \mathrm{~A}$ 位 点的比例. (c) $\mathrm{m}^{6} \mathrm{~A}$ 在基因上的占比. (d)新生 $\mathrm{m}^{6} \mathrm{~A}$ 在基因上的占比. (e) 高通量测序验证 $\mathrm{m}^{6} \mathrm{~A}$ motif. (f) 新生 $\mathrm{m}^{6} \mathrm{~A}$ 和总 $\mathrm{m}^{6} \mathrm{~A}$ 在不同区段上的比较.

Figure 5 High-throughput sequencing analysis of nascent $\mathrm{m}^{6} \mathrm{~A}$ and total $\mathrm{m}^{6} \mathrm{~A}$. (a) Pie chart presenting the fraction of $\mathrm{m}^{6} \mathrm{~A}$ sites in each nonoverlapping RNA segment. (b) Pie chart presenting the fraction of nascent $\mathrm{m}^{6} \mathrm{~A}$ sites in each nonoverlapping RNA segment. (c) The proportion of $\mathrm{m}^{6} \mathrm{~A}$ in different segments of the gene. (d) The proportion of nascent $\mathrm{m}^{6} \mathrm{~A}$ in different segments of the gene. (e) High-throughput sequencing to verify $\mathrm{m}^{6} \mathrm{~A}$ motif. (f) Comparison of nascent $\mathrm{m}^{6} \mathrm{~A}$ and total $\mathrm{m}^{6} \mathrm{~A}$ in different sections.

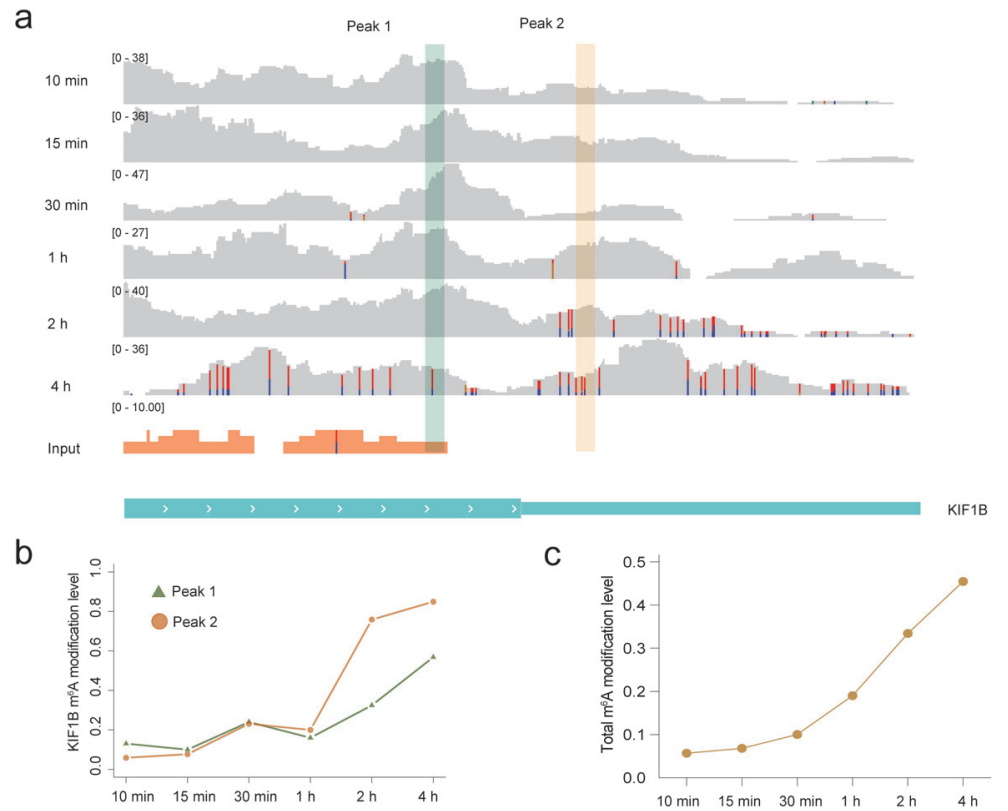

图 6 高通量测序分析 KIF1B 和总体修饰水平变化差异. (a, b) KIF1B 上的修饰水平变化. (c) 总 $\mathrm{m}^{6} \mathrm{~A}$ 修饰水平变化.

Figure 6 High-throughput sequencing analysis of KIF1B and overall modification level changes. (a, b) Modification level change on KIF1B. (c) Modification level change of total $\mathrm{m}^{6} \mathrm{~A}$. 


\section{3 结论}

采用亚硫酸钠介导 $\mathrm{s}^{4} \mathrm{U}$ 到 $\mathrm{C}$ 的反应, 并通过优化条 件确定了适用于核酸样本的反应条件, 反应效率可以达 到 90\%以上, 并能顺利检测新生 RNA, 该方法将亚硫酸 钠与 $\mathrm{s}^{4} \mathrm{U}$ 发生加成反应生成 $\mathrm{SO}^{3-}$ 取代产物从而避免了 使用氧化剂, 与 TimeLapse-seq 中使用过氧化物和 TUC-seq 中使用 $\mathrm{OsO}_{4}$ 相比使用的试剂环保安全无毒害 作用，不会对其他碱基造成损伤而产生背景信号. 将其 与 $\mathrm{m}^{6} \mathrm{~A}-\mathrm{seq}$ 结合成功将其应用于检测新生 $\mathrm{m}^{6} \mathrm{~A}$, 并找到 新生 $\mathrm{m}^{6} \mathrm{~A}$ 与总体修饰水平的异同, 通过进一步分析发 现了单个基因修饰水平上的变化, 为 $\mathrm{m}^{6} \mathrm{~A}$ 功能分析提 供了新方法.

\section{4 实验部分}

\subsection{HPLC-MS 分析}

每 $10 \mathrm{~cm}$ 细胞培养血中接种 $3 \times 10^{6}$ 个 HEK293T 细 胞, 并生长 $24 \mathrm{~h}$. 然后将 $\mathrm{s}^{4} \mathrm{U}$ 添加至培养基中, 最终浓 度为 $50 \mu \mathrm{mol} / \mathrm{L}$, 培养 $24 \mathrm{~h}$. 使用 TRIzol 试剂(Invitrogen) 提取总 RNA. 使用 Dynabeads Oligo $(d T)_{25}$ (NEB) 提取 mRNA, 然后去除 gDNA. 纯化后的 RNA 使用 RNA 打 断试剂盒 RNA Fragmentation Reagents (Invitrogen)打断 后反应. 纯化酶解后进行 HPLC-MS 分析.

\section{2 一代测序}

使用 oligo RNA(含 $\mathrm{s}^{4} \mathrm{U}$ )进行转化反应, 纯化后进行 逆转录, 取 $50 \mathrm{ng}$ 逆转录产物, 使用擎科试剂盒 $1 \mu \mathrm{L}$ pEASY-T5 Zero Cloning Vector 进行载体构建.

\subsection{RNA 文库构建}

每 $10 \mathrm{~cm}$ 细胞培养血中接种 $3 \times 10^{6}$ 个 HEK293T 细 胞, 并生长 $24 \mathrm{~h}$. 然后将 $\mathrm{s}^{4} \mathrm{U}$ 添加至培养基中, 最终浓 度为 $500 \mu \mathrm{mol} / \mathrm{L}$, 并分别培养 $10 \mathrm{~min}, 15 \mathrm{~min}, 30 \mathrm{~min}, 1$ $\mathrm{h}, 2 \mathrm{~h}$ 和 $4 \mathrm{~h}$. 使用 TRIzol 试剂(Invitrogen)提取总 RNA, 取 $10 \mu \mathrm{g}$ 总 RNA 打断后进行 $\mathrm{s}^{4} \mathrm{U}$ 转化反应后去除 $\mathrm{gDNA}$. 对照组取 $100 \mathrm{ng}$, 实验组取 $5 \mu \mathrm{g}$ 上述 RNA 样品进行 $m^{6} \mathrm{~A}$ 免疫共沉淀(可得约 $100 \mathrm{ng}$ RNA). 去除 rRNA 后,
进行文库构建.

\section{4 测序数据过滤与基因组比对}

使用 cutadapt 去除原始双端测序数据的接头序列, 使用 fastuniq 软件去除测序过程中产生的 PCR 重复. 通 过比对人类 rRNA 数据库去除 rRNA 序列, 之后通过 hisat 2 软件将过滤 rRNA 后的 reads 比对人类基因组数据 库(hg38, www.gencodegenes.org; 软件比对参数为: $-\mathrm{mp}$ 4,2 -rna-strandness RF -no-mixed -no-discordant), 比对完 成后仅保留唯一比的 fragments 进行下一步的分析.

\section{5 突变位点鉴定与半衰期计算}

通过本实验室内部自行编写的脚本找出与参考基 因组序列不同的位点, 并通过对照组数据排除出假阳性 位点.

\section{6 基因表达量的计算}

通过 HTSeq2 软件统计了每个基因上的 counts 数, 之后通过 FPKM 公式计算得到每个基因的 FPKM 值.

\section{References}

[1] Ping, X.-L.; Sun, B.-F.; Wang, L.; Xiao, W.; Yang, X.; Wang, W.-J.; Adhikari, S.; Shi, Y.; Lv, Y.; Chen, Y.-S.; Zhao, X.; Li, A.; Yang, Y.; Dahal, U.; Lou, X.-M.; Liu, X.; Huang, J.; Yuan, W.-P.; Zhu, X.-F.; Cheng, T.; Zhao, Y.-L.; Wang, X.; Danielsen, J. M. R.; Liu, F.; Yang, Y.-G. Cell Res. 2014, 24, 177.

[2] Frye, M.; Harada, B. T.; Behm, M.; He, C. Science 2018, 361, 1346.

[3] Roundtree, I. A.; He, C. Curr. Opin. Chem. Biol. 2016, 30, 46.

[4] Fu, Y.; Dominissini, D.; Rechavi, G.; He, C. Nat. Rev. Genet. 2014, $15,293$.

[5] Jia, G.; Fu, Y.; Zhao, X.; Dai, Q.; Zheng, G.; Yang, Y.; Yi, C.; Lindahl, T.; Pan, T.; Yang, Y.-G. Nat. Chem. Biol. 2011, 7, 885.

[6] Gasser, C.; Delazer, I.; Neuner, E.; Pascher, K.; Brillet, K.; Klotz, S.; Trixl, L.; Himmelstoss, M.; Ennifar, E.; Rieder, D.; Lusser, A.; Micura, R. Angew. Chem. Int. Ed. 2020, 59, 6881.

[7] Herzog, V. A.; Reichholf, B.; Neumann, T.; Rescheneder, P.; Bhat, P.; Burkard, T. R.; Wlotzka, W.; von Haeseler, A.; Zuber, J.; Ameres, S. L. Nat. Methods 2017, 14, 1198.

[8] Schofield, J. A.; Duffy, E. E.; Kiefer, L.; Sullivan, M. C.; Simon, M. D. Nat. Methods 2018, 15, 221.

[9] Riml, C.; Amort, T.; Rieder, D.; Gasser, C.; Lusser, A.; Micura, R. Angew. Chem. Int. Ed. 2017, 56, 13479.

[10] Chen, Y.; Wu, F.; Chen, Z.; He, Z.; Wei, Q.; Zeng, W.; Chen, K.; Xiao, F.; Yuan, Y.; Weng, X.; Zhou, Y.; Zhou, X. Adv. Sci. 2020, 7 , 1900997. 